\title{
'Knight of the Whistle': W.P. Harper and the Impact of the Media on an Association Football Referee
}

\author{
The media interest in the association code of football is an accepted part of the \\ modern form of the game. The impact of this increased attention from the media \\ can be traced both through an understanding of the developing media/sport \\ relationship during the 1920s and 1930s and specific examples of this burgeoning \\ relationship through the career of W.P Harper, a prominent referee, who recorded \\ and maintained some of the press coverage he received during his career. This \\ article explores the embryonic impact of the media on referees, utilising W. P. \\ Harper as an example, charting incidents during his career and the associated \\ media coverage that these high profile examples received. The consideration \\ afforded to the early role of the media, and the direct impact on referees, assists \\ in a greater understanding of the development of this relationship and therefore \\ an increased comprehension of the role of the media in Association Football in \\ the game today.
}

Keywords: W. P. Harper; referees; Association Football; media; folk devils. 


\section{Introduction}

W. P. Harper was an Association Football referee. Known as Percy, he principally refereed during the 1920s and 1930s in the top divisions of the English Football League (Figure 1). Alongside other notable achievements during his career such as officiating international matches and in the Football League, Harper was selected as a linesman for the 1926 FA Challenge Cup Final between Bolton Wanderers and Manchester City and the 1931 FA Challenge Cup Final between Birmingham City and West Bromwich Albion. The pinnacle of Harper's career was officiating the 1932 FA Challenge Cup final between Arsenal and Newcastle at Wembley stadium. Despite the importance of this occasion in Harper's career as a referee it also proved to be one of the most challenging situations he faced, due to a controversial equalising goal awarded to Newcastle United when the ball appeared to go out of play prior to the goal being scored.

Figure 1 near here

This incident resulted in a significant amount of media and press attention following the 1932 cup final, which provides a specific example of the growing interest in Association Football, the referee and the consequences of the decisions made by match officials.

This article considers critical aspects in the career of W. P. Harper through the media, predominantly utilising newspaper cuttings, personal correspondence, letters, pictures and match programmes ${ }^{1}$. The career of one of the most prominent referees of the 1920s and 1930s is contextualized through a critical view of the evolving sport/media relationship of the time, and the beginning of the written press interest in Association Football and in particular contentious refereeing decisions. 
Initially this paper considers the introduction, growth and impact of the media on sport and Association Football as a means of framing the context and background that referees operated within.

\section{The Media, Sport and Association Football}

The reporting, dissection and analysis of referee performances and decisionmaking is part of the modern game and also part of the media consumption of Association Football. The nature of the attention to which referees are now exposed has evolved considerably over time, and discussed sporadically in an academic context, ${ }^{2}$ however the level and intensity of this media interest has been questioned more recently. ${ }^{3}$ The intensity of the media focus today notwithstanding, there is little doubt that this attention has increased over time corresponding and intertwined with the growth of various forms of media, such as the written press, radio and television.

Association Football and modern sport more generally have been moulded from the nineteenth century by the ways in which the press, then radio and latterly television have reported matches and tournaments, highlighted particular features of play and drawn attention to particular players as well as refereeing decisions. It was the written press that first elevated some sportsmen and women into national celebrities in the nineteenth century. The interest of the press meant an enlarged mass spectator market, an increase in the public awareness of sport and, as a by-product, greater interest in the outcome of matches as well as player and referee performances.

As a result by the mid-nineteenth century, specialist sport publications began to emerge, such as Sporting Life (1859), the Sportsman (1865), the Sporting Chronicle (1871) and Athletic News (1875). ${ }^{4}$ Because of the growth of the sport-specific periodicals towards the middle and end of the nineteenth century, it was inevitable that 
the mass circulatory newspapers of the time accepted that sport was something in which the general public were interested.

By 1896, after noting the success of the sport-specific publications, the Daily Mail began the era of mass circulation newspapers and covered sport on the back pages to attract and maintain a readership that was evidently conspicuous. ${ }^{5}$ By 1900 the Daily Mail was selling over a million copies per day. In addition to the Daily Mail from 1895 the News of the World had been devoting 14 per cent of its space to sport, including football, and by 1905 the News of the World dedicated 15.75 per cent of its total content to sport. ${ }^{6}$ As the popularity of sport and Association Football increased in society into the twentieth century, this was mirrored in the press coverage, with the growing prevalence of sport and the increased celebrity of some sporting figures evidencing sport's prominence with the press. ${ }^{7}$

In the 1920s and 1930s supporters followed football in a variety of ways. One of the most obvious ways of following football other than attending matches was to read about matches in newspapers. To that end, the press provided a source of free publicity for the game through the coverage of matches and the publishing of scores. ${ }^{8}$ This publicity and associated interest that it provoked can also impacted upon referees and therefore the wider game. As press coverage grew between the two world wars so did sporting coverage, increasing the importance of the relationship between football and the media. By 1940 newspapers such as the Express, Herald, Mirror and Mail each boasted circulations of between 1.45 and 2.6 million, while both the Sunday newspapers News of the World and the People reached well over 3 million. As circulation grew the space devoted to reporting football increased, accounting for approximately 10 per cent of the overall coverage in the News if the World and the People by the end of the 1930s. ${ }^{9}$ 
Comparatively quickly referees were contending with a growing level of attention and scrutiny to which they had never previously been exposed. This had led, in turn, to refereeing decisions becoming more of a discussion point, particularly when they were perceived to have influenced a game or led to a controversial goal. The frequency of these incidents was not assisted by the lack of formal training that referees were receiving at this time. ${ }^{10}$

Following the impact that the written press had demonstrated in football, the invention and subsequent introduction of radio into British life meant further changes and developments in the way that Association Football was reported and covered by the media. In the 1920s radio began to have an impact alongside that of the written press. Radio broadcasts offered the public interested in football immediacy, a live commentary and a tangible link to the match and their team as well as raised excitement. All aspects that the written press could not offer. The BBC developed the range and coverage of sport broadcasting during the 1920s, 1930s and 1940s ${ }^{11}$ and alongside the advent of cinema newsreel in the 1920s both mediums significantly increased the coverage of sport.

Radio in particular had a substantial impact upon the game of Association Football. Wireless licenses rose from two million in 1927 to 9 million by 1939, a total that represented 71 per cent of all UK households. ${ }^{12}$ As well as the growth of radio during the 1920s and 1930s, and the involvement of the BBC in this process, the BBC was also involved with the introduction of television. BBC television began broadcasting to a few households in November 1936 and in April 1938 the BBC broadcast the first televised football match between England and Scotland from Wembley to a London-based audience of 2,000. Supporters were already used to seeing football on screen with the use of cinema newsreels, even if it was often several days, 
even weeks after the event had taken place. ${ }^{13}$ Changes in the scale and method of television coverage has contributed to an increasing focus on referees. The FA Cup Final was first televised in $1939^{14}$ whereas Football League matches were not shown on the BBC until the $1950 \mathrm{~s}^{15}$ with sports initially wary of live TV coverage, believing that it could be detrimental to spectator attendance. ${ }^{16}$

Amongst all of the developments within the media and society more generally during the 1920s and 1930s, referees were directly influenced by some of these changes. The increased attention paid to Association Football through the written press, radio and latterly during the 1930s television was, consequently, affecting journalists' and the general public's view of the role and the importance of the referee. Officiating during this time period was W. P. Harper, and some of the changes that Association Football and also referees were experiencing can be considered through some of the incidents, matches and occurrences recorded and maintained by Harper throughout his career as a referee that he deemed important enough to record, document and preserve.

\section{The Early Career of W. P. Harper}

Harper was considered one of the foremost referees of his time. Officiating during the same time period as other notable officials such as Stanley Rous and Harry Nattrass for example ${ }^{17}$. Harper developed his refereeing during the 1920 s and achieved most of his notable appointments to 'big' matches during the 1930s. However, the 1920s were a decade that shaped Harper's later achievements as a consequence of some of the incidents that he experienced.

Harper was already a referee in demand towards the end of the 1920s and as such was invited to officiate in America in a series of 'friendly' matches. Correspondence between Harper and then secretary of the Football Association (FA), F. J. Wall on $26^{\text {th }}$ July 1927 refers to these 'friendly' matches in America, with Wall 
stating that, 'It would be quite in order, under our Rules and Regulations, for you to act as Referee in the United States if you are invited to do so'. Harper had raised the question of substitutes whilst officiating in America in the previous correspondence, to which F.J. Wall had responded that. ' ... there should be a mutual under-standing before the games commence' regarding the number of substitutes allowed. ${ }^{18}$ The correspondence demonstrates the growing demand that Harper was beginning to command, even within international football, towards the end of the 1920s. Despite Harper's increase in popularity among the refereeing fraternity, there was evidence in the 1920 s that it was increasingly more acceptable to criticize referees. There are examples of this criticism during Harper's career, principally due to the fact that Harper was involved in a number of controversial incidents.

An incident recorded in 1926, although critical of Harper's performance is not particularly forceful in the critique. In the Athletic News Harper was criticized for his performance in the match between Oldham Athletic and Swansea City which ended with Oldham winning 5-2. The newspaper report identified Harper's decision making as causing the players to be ' ... ruffled, and, through faulty refereeing ... subsequently subjected to the indignity of a general caution in the centre of the field'. The report continued, stating that as a journalist he generally:

... dislike offering criticism, because I understand the difficulties of the job, and am reluctant to say anything which will reduce the confidence of the public in present-day control and pave the way for vocal outbursts. To remain silent, however, is not always wise. ${ }^{19}$

Although there is criticism of the performance, this critique is tempered and relatively considered towards Harper. However, Harper also kept records of particular complaints from clubs regarding his performances, and these complaints are more serious in accusation. 
On $4^{\text {th }}$ February 1926 a complaint letter from Stoke City regarding their FA Cup match with Swansea Town was lodged by the Stoke secretary T. Mather to the FA, through Worcestershire FA as Harper's County Association. Mather accused Harper of '... a few very serious mistakes which had an effect on the result'. In particular the protests of Stoke City revolved around a goal that was not given despite their assertion that, 'we had the ball well over the goal line in the first few minutes of the game'. The letter from Mr. Mather also stated, ' ... after the match the Captain of Swansea, Sykes and the goalkeeper Deoon admitted it was a goal'. Alongside this complaint Harper was also accused of stopping the game for $2 \frac{1}{2}$ minutes in the first half to 'speak to the crowd' and because of this a goal was scored ' $31 / 2$ minutes over the 45 minutes as he blew for half time $1 / 2$ a minute late' ${ }^{20}$ Harper responded to the complaint from Stoke City in a letter dated $8^{\text {th }}$ February 1926 , to the FA and Stoke City regarding the procedural issues identified during the match with Swansea City. In the letter of response Harper admits that he did not, ' ... consider it necessary even to consult the linesman' and also that he '... was not requested to do so by Stoke players'. ${ }^{21}$ Perhaps more enlightening is the admission by Harper that he used the judgement of the crowd in order to try and make a decision on a particular incident during the match.

Harper relays in the letter to Mr. Wall at the FA that ' ... the crowd drew my attention to Langford [a Swansea player] doubled up apparently in pain and holding his stomach'. Harper also reported that he did not see the particular incident that led to the player apparently becoming injured, and after consulting the linesman he still did not know what had led to the incident. Harper stopped the game as the crowd continued to 'barrack' Johnson, who was the player alleged to have injured Langford. This led to Harper conversing with the crowd directly: 
I stopped the game and went to the popular side of the field to speak to the spectators but they would not at first listen still requesting the dismissal of Johnson from the field of play but as I persisted in my endeavours they eventually listened to what I had to say and the play proceeded. ${ }^{22}$

Harper kept records, in some cases, of players that he had reported for offences such as ungentlemanly conduct. When officiating the English League Division Three Southern match between Northampton and Plymouth, which Northampton won 3-0, Harper reported the Plymouth players, Hardie (left half), Russell (right back) and Titmus (left back), in a letter to F.J. Wall at the FA in1928. The players were reported because they '.. openly disputed my decisions and it appeared to create a feeling of discontent amongst their players'. In fact Harper alleged that the left back for Plymouth, Titmus, threatened him because he was going to ' ... ask his manager to report me for as he said 'trying to push him off the field with my hands', ${ }^{23}$ something which Harper strongly disputes in his letter to the FA. Despite the issues outlined and explained in these matches, the level of media attention was not as vociferous as a match that Harper officiated in the FA Cup.

At the beginning of the 1930s Harper was officiating an FA Cup match between Tottenham Hotspur and Manchester City on $11^{\text {th }}$ January 1930 which ended in a 2-2 draw. This match and the decisions made by Harper during the match drew a significant level of media attention. The legality of two of the goals sparked a debate which also saw an ex-referee, H. J. Weber, wrote a personal letter to a newspaper to further criticize the performance of Harper. The letter alleges that Harper, as the referee, was the only individual that had any doubt about the fact that Manchester City had scored a legal goal and that the ball had crossed the goal line. The former referee continues to state that: 
... I have no hesitation in stating that Mr. Harper did not enjoy a good match. The other goal which the Spurs scored and which he disallowed because he ruled Osborne offside, was another instance of his absolute inability to correctly interpret movements. From the position that Osborne received the ball it was absolutely impossible for him to be offside. ${ }^{24}$

Further to this criticism the letter also alleges that Harper had been influenced by the Manchester City players when awarding their controversial goal. The letter continues to assert that if the Tottenham Hotspur players had also protested in a similar fashion it would have achieved the same result, 'had the Spurs displayed the same attitude as the Manchester players they may also have induced the referee to consult a linesman, but they accepted his ruling to their loss'. ${ }^{25}$

Another newspaper report printed in 1930, quoted Harper directly after the match referring to the Manchester City goal with Harper stating that, 'I never had any intention of disallowing the goal'. This article was taken from Harper's personal collection and on the original article Harper wrote that he did not give this quote to this particular journalist or newspaper directly after the match, writing above the article 'this is absolutely incorrect'. ${ }^{26}$

As a consequence of this match and the goal awarded, Harper received a personal letter from H. J. Weber related to the letter that the same individual had published in the Sporting Life, which commented both on Harper's performance during the match and the press interest that had been evident since the game. Weber alleges that his original letter was altered by the newspaper and attached the actual copy of the letter that he sent to the Sporting Life. The letter begins with Weber reiterating the media and press attention that Harper's performance had attracted, 'you are probably aware as to the many press reports which have appeared in connection with your indifferent rulings ... ${ }^{27}$ The letter continues to question Harper and the quote attributed 
to him after the match, published in the Evening News. ${ }^{28}$ Weber asks Harper, ' $\ldots$ if you never had any intention of disallowing the goal, why did you give a definite decision in Tottenham's favour? Your reason for so doing I fear only you yourself can know'. The letter continues to allege that Harper had no intention of consulting the linesman until the Manchester City player, McMullan ‘ ... finally pushed you towards the linesman whom you then consulted' and that by trying to explain the incident and the clarity with which Harper made the decision '... is absolutely contrary to fact'. ${ }^{29}$

\section{Positive Press Coverage}

As the 1930s progressed the media and written press in particular were consistently reporting matches and decisions involving Harper. This coverage included articles that praised Harper's refereeing, exemplified in a match report by P. J. Moss. Moss described the Tottenham Hotspur versus Sheffield United match which Tottenham won 4-1 and identified Harper as ‘ ... England's best referee’ who ‘ ... never made a slip during a very dull game', ${ }^{30}$ whilst the Topical Times, in an article entitled 'The World's Best Referee', went a step further claiming that, 'we agreed on the world's best - Percy Harper of Stourbridge' ${ }^{31}$

Meanwhile, a letter praising Harper from a member of the press demonstrates that there were examples of journalists during the 1930s reporting and commenting upon the performance of referees both positively and negatively. The personal letter is from a Mr. J. T. Rose, who was the Sports Editor in the Northern Office for the Daily Express. The letter, dated 24th February 1931, was written in praise of the recent performance of Harper in a match between Manchester City and Sheffield Wednesday. The letter states 'I am a hardened press man, but I was impressed with your handling of the city v. Wednesday match on Saturday. I have an idea you may not have seen my 
report of the match, so I enclose it herewith. I think you ought to get the cup final; I hope you will' 32

The reporting of performances and the standing of referees such as Harper, was becoming more commonplace and was also drawing more attention to referees as a central part of the game of Association Football. The growing focus on the referee was evident, although perhaps the most obvious difference to the game today was the positive reporting on the match official which was still evident in the 1930s, and is more difficult to find in reports on the modern game of Association Football.

This positive reporting was particularly evident in the Oldham Evening Chronicle, in 1933, in an article entitled 'Popular Referee!' where Harper was praised for an exemplarily performance:

... next to Athletic's dashing football the most enjoyable feature of the match was the way in which Mr. W. P. Harper of Stourbridge, controlled the game. Mr. Harper not only controlled the game but he seemed to enter into the spirit of it, joking with the crowd at the touchline, chatting with the players and generally doing everything he could to make the game one of the happiest of the season. He soon earned the admiration of the crowd and his readiness to admit what was obviously a wrong decision, only heightened their esteem, and when he assisted to carry off an injured player, he was warmly cheered. No wonder Mr. Harper is given charge of cup finals. He has the tact and the sense of humour which every referee should posses. ${ }^{33}$

It is also worthwhile noting the difference in approach of referees at this time, which can be examined through the way that the Oldham Evening Chronicle reported on Harper's performance and interaction with the crowd and the players. It would be unusual to find a referee in the modern game of football commented upon and praised within a report for 'joking with the crowd', 'chatting with the players', demonstrating ' ... readiness to admit what was obviously a wrong decision' and also assisting 'to carry 
off an injured player'. Many of these actions would not be accepted in the modern game of football, and the way that the media would report actions such as this would are very different.

Examples of the positive reporting by the press can also be found in club specific official programmes. An official programme of Burton Town FC, from 1935, thanked Harper for the 'admirable manner in which he handled the game, and his reception from the spectators at the close was a fitting tribute to a 'knight of the whistle'. ${ }^{34}$ Moreover, in the 'The County Express' a local newspaper in Worcestershire, an article entitled, 'Mr. W. Percy Harper. A Member of the English Football Association' discussed the promotion of Harper to the Council at the Football Association:

Of the many honours which have been bestowed upon Mr. W. Percy Harper in his long and interesting association with football, his appointment as the Worcestershire F.A. representative to membership of the council of the English Football Association is the greatest, and it is the first time the honour has been held by a Stourbridge resident. ${ }^{35}$

Harper was evidently a respected figure within refereeing, both at league clubs and within his local community. Harper's standing at some clubs is further evidenced by a report in the Swindon Evening Advertiser, published in 1938. Harper was praised in an article entitled 'Mr. Harper shows how the game should be handled', with the byline 'no irritating stoppages in Reading's match at Cardiff'. The article is not entirely complementary describing Harper as '... a bit of a showman', although the article also states that:

... he is a referee with personality and a man who knows his job from $\mathrm{A}$ to $\mathrm{Z}$, and it would be a good thing for football if more referees carried out their duties with the same firmness, good judgement and discretion. ${ }^{36}$ 
The positive and negative media reports related to, and kept by Harper have highlighted that the press reports were at least reasonably balanced during his career. There is evidence of criticism if Harper was deemed to have performed poorly, and there is also evidence of praise if Harper was perceived to have performed well in a particular match. Despite this balance in evidence, there are examples of incidents which were treated far more harshly by the media, and in more detail than the incidents covered so far in this paper. The first example of this is a game that Harper officiated between Dolphin and Cork that took place in Ireland.

\section{Dolphin versus Cork}

Alongside the newspaper reports that Harper retained in his personal collection, he also had correspondence with supporters, and two of these letters were kept by Harper, perhaps due to the severity and seriousness of the content. Following a match which Harper refereed in Ireland, between Dolphin and Cork, which Dolphin won 3-2, there was significant newspaper criticism. Following this criticism Harper received a letter from a supporter which evidenced that the strength of feeling surrounding matches in Association Football during the 1930s was extremely high. A newspaper report in the Irish Press following the match in February 1932 was entitled 'Rough luck: Goal that was not a goal'. The article stated that the award of the winning goal to Dolphin was ' ... an amazing decision on the part of the referee - Mr. W. Harper (Stourbridge)' ${ }^{37}$ Following this article the Irish Independent managed to obtain and adapt a version of the report submitted by Harper following the game. The report concerned Harper's actions regarding the goal that decided the contest, and was entitled 'Cork out of free cup: Referee's report adopted.' The report quoted the official response from the Protest and Appeals Committee after Cork had protested that the ball did not cross the goalline 
and therefore a goal should not have been awarded, and also that Harper had not played the full amount of time for the match.

The Protest and Appeals Committee met and ascertained that 'it was unanimously decided to dismiss the protest under the provisions of Law 13 of the Laws of the Game.' In addition the newspaper report also quotes Harper's views on the incidents and states that Harper argued, 'I emphatically say that I was in a sufficiently good position to judge that the ball had passed completely over the line before it was kicked out by the Cork player. It was, therefore, a goal which I gave.' Harper also added, in respect of the amount of time played, 'I can say that I played the correct and necessary time, viz., 45 minutes actual playing time in each half, and I allowed for all stoppages'.38

The response to the match, the result and also the complaint and subsequent rejection of the complaint by the Protest and Appeals Committee led to further issues for Harper, which were increased by the media attention that this incident was afforded. Following this media attention, some of which has been identified here, Harper received a letter from a Cork supporter, which both questioned his integrity and suggested he had taken money to award the goal to Dolphin, threatened his life should he ever return to Cork (figure 2). The supporter asked, ‘ ... how much money your hand was greased for by Dolphin', although the letter letter takes a more sinister tone as it progresses by threatening Harper, ‘ ... if you are ever thinking of coming to Cork to referee a match I think you better cancell [sic] it because you dirty bastard your life will be taken' with the letter singed 'fair play'.

Figure 2 near here

Harper also received a personal letter from the linesman that participated in the match between Dolphin and Cork. The linesman, Mr. Patrick Barrington, stated that 
there was a picture of the incident in the Dublin Independent which was alleged to have shown the goal line (figure 3). However, Barrington believed that the picture that appeared in the Dublin Independent was 'fake' and was not a picture of the incident in question because of the position of some of the players and the fact that it took the newspaper, ' $\ldots$ from Sunday $7^{\text {th }}$ Feb. to Friday $12^{\text {th }}$ to publish the photograph' ${ }^{39}$

Figure 3 near here

\section{Moral Panic, Folk Devils and Referees}

Media coverage of referees has undoubtedly evolved over time. The experiences of Harper during the 1920s and 1930s were at the start of the increasing media interest and coverage of football and refereeing. The media and press coverage appears to have added to the profile of the incident in Cork and has increased both public outrage and the wider perception of Harper. In order to explore and explain the effect that this interest was beginning to have on referees and the wider game of football the work of Stanley Cohen can be examined and applied to football.

Cohen coined the terms 'folk devils', 'moral panic' and 'deviancy amplification' in his seminal work 'Folk devils and moral panics: the creation of the mods and rockers'. Cohen argues that the creation of moral panic by the media, law enforcement, politicians, action groups, and the general public are out of context and proportion with the real 'danger' or 'threat' to society. ${ }^{40}$ Evidently this cannot be said of referees, however, some of the concepts of the moral panic theory as well as the referee being chastised as a folk devil can be applied. That is not to say that this places football and referees in the same bracket as the mods and rockers, or, when applied to football, the hooligan problem particularly evident in the 1970s and 1980s in England. ${ }^{41}$ Rather, the intention here is to rationalize and explain the development of media interest in refereeing. 
The concept of 'moral panic' as well as 'deviancy amplification' can be applied to the aftermath of the goal line incident in the match between Dolphin and Cork when linked to the mass media. ${ }^{42}$ Cohen argues that the concepts of 'moral panic' and 'deviancy amplification' were conceived in the 1960s, however incidents such as that which Harper was involved can assist in arguing that these incidents actually occurred earlier than originally believed in the sporting world. ${ }^{43}$

The media are involved in three principal roles when moral panic dramas are conceived; firstly, the media set the agenda by selecting events, occurrences and incidents they deem as newsworthy and subsequently selecting filters to decide which of these events are candidates for moral panic; secondly, the media proceed to transmitting the images. In the case of W.P. Harper and the match in Ireland this was undertaken through pictures of the incident in newspapers. The media can then control the sharpening or dumbing down of the rhetoric of moral panic related to the incident in question; thirdly, the media can be seen to break the silence and transmit the claim by claims-makers or the media themselves. In the case of the incident in Ireland the claim was related to the goal that was not given that many supporters, and members of the media, believed should have been awarded. ${ }^{44}$

From a rational viewpoint it could be considered an erroneous concept to refer to referees as 'folk devils' who assist in creating 'moral panic'. However, a counter argument to this view, and the stance that is taken in this article, is that a moral panic is, in fact, an ideal 'it does not have to fit all cases or to be a full explanation. ${ }^{45}$ A moral panic can also be described as an abstract thing or a 'model of a process', ${ }^{46}$ with the application of taxonomies to popular fears or issues inherently difficult. ${ }^{47}$

There are five crucial elements, or criteria that characterize a moral panic. Goode and Ben-Yehuda identify these components as concern, hostility, consensus, 
disproportionality and volatility. ${ }^{48}$ Furthermore, three specific theories of moral panic are identified, the grassroots model, the elite engineered model and the interest group theory. Of these theories, the grassroots model is the most applicable to referees in Association Football. The grassroots model argues that moral panic begins with the public, that the concern is widespread, genuine and that there can also be mistaken or exaggerated concern. ${ }^{49}$ In addition there are certain elements that are a necessity of a successful moral panic, with the most prevalent and relatable here the requirement of a suitable enemy who embodies the problem and evokes concern, feelings of outrage and who is regarded as a soft target who is easily denounced and holds little power. ${ }^{50}$ In the case of this article these concepts can be applied to the referee.

The referee is viewed as the enemy by football supporters, and often seen as 'the problem' when their team loses. These beliefs often evoke concern amongst supporters and the media related to contentious refereeing decisions with the referee inducing feelings of outrage amongst supporters if they perceive that decisions have gone against their team. This focus and attention renders the referee a soft target who is easily criticized and denounced. Nevertheless, the theory of moral panic and folk devils has, over time, drawn attention to the importance of empowering folk devils so that they can challenge social control. ${ }^{51}$ In the case of refereeing this can be evidenced by the invitation that has been extended to referees, such as W.P. Harper, to write and contribute to national newspapers through a personalized column. This has, in effect, historically given referees a right to reply and a platform to challenge the social norms or control to which they have been subjected by the media and the general public.

Despite this voice in the written press, high profile incidents such as the match in Cork and the 1932 FA Cup Final meant a continued presence in the national media. 


\section{The 1932 FA Cup Final}

Further to the events that occurred in Cork, perhaps the performance and decision that received the most media coverage during Harper's career was during the 1932 Cup Final with the award of the equalising goal for Newcastle United, in a match that Newcastle eventually won 2-1 against Arsenal. Harper was awarded the role of officiating the 1932 FA Cup Final via a letter from the FA in April 1932. ${ }^{52}$ The letter was written and signed by Frederick Wall, Secretary of the FA at that time (Figure 4).

Figure 4 near here.

There were newspaper articles and stories on the Cup Final appointment of Harper, and Harper himself was also sent several congratulatory messages and personal letters from the President of the Referees' Association, E.H. Spiers. This letter came before Harper was officially announced as the FA Cup Final referee and Spiers states in the letter that, 'the press this evening intimate that you are to be recommended to take the final. ${ }^{53}$ Even before the official announcement of the referee for the Cup Final in 1932 the written press were involved in the reporting of rumour and conjecture related to Association Football. Harper also received congratulatory correspondence from W.F. Bunnell, President of the Association of Football League Referees and Linesmen, ${ }^{54}$ again before the official letter was sent from the FA to Harper confirming him as their choice to officiate the final.

The media also wanted to hear the experiences and interpretation of the FA Cup final referee. Thomson's Weekly News asked Harper to contribute a column to their newspaper after his Cup Final appearance. In an article entitled 'Banned by Irish League on Eve of Wembley', Harper recounts how he had to reject the appointment to a match in the Irish League but did give them ten days notice of his inability to officiate the match to which he had been assigned. Nevertheless, the Irish League decided to bar Harper from officiating any further matches until the following season, although Harper 
also argued that, ' ... as yet I have received no official intimation' ${ }^{55}$ Despite Harper's arrangement with the media, even in 1932 referees were being warned against engagement with the press. A separate letter from F. Wall at the FA instructed Harper as well as the other Cup Final officials that, ' ... the Council does not consider it consistent with the dignity of the position of such officials that they should appear in Talkie Films, or on the stage of any Theatre, Music Hall, or other place of entertainment ... ${ }^{, 56}$

Referees and those in managerial and administrative roles were evidently aware and cautious of the media and the press at the beginning of the 1930s. Certainly in the case of the 1932 FA Cup Final the reticence for referees to deal with the written press became obvious as the game took place and the consequences of the decisions of Harper, became evident as a controversial goal was allowed and scored, subsequently contributing to a Newcastle to win.

The 1932 FA Cup Final took place on Saturday $23^{\text {rd }}$ April, ending with Newcastle winning 2-1. This final can be identified as an example of the growing influence and interest within the media, the relationship with sport and more specifically here, Association Football (Figures 5, $6 \&$ 7). The equalising goal scored by Newcastle, was the subject of controversy regarding whether the ball had gone out of play prior to the goal being scored. Newspapers examined the video stills from various angles in the days following the match, in order to attempt to determine whether Harper had been correct to award the goal.

Figure 5 near here.

Figure 6 near here.

Figure 7 near here.

The continued media and in particular, press coverage, of the FA Cup Final meant that Harper was again targeted by certain supporters who wanted to vent their 
anger at the decisions and the eventual outcome of the match. The extended media coverage can certainly be considered in the same way as the coverage that Harper was afforded following the Dolphin versus Cork match in Ireland. As a result of the press coverage Harper received another anonymous letter, this time from an Arsenal supporter (figure 8); this communication was accusatory, asking Harper how much he got ' ... for letting Newcastle win!!!' The letter also states that Harper would, ‘ ... go down in history as the ref. who sold a Cup Final' also alleging that Harper 'gave Newcastle every chance to win and the Arsenal none'.

Figure 8 near here.

The media interest following the 1932 FA Cup final further demonstrates the increased media interest in Association Football and also the changing role of the referee within the game. Even in the 1930s there was an acceptance that the role and importance of the referee was shifting. This, alongside the increase in available technology such as cameras, meant that there was a greater scrutiny on the performance of the referee and as a result a growing pressure on these match officials.

\section{Two Referee Trial}

Another facet of Harper's career widely covered by the written press was the trial of two referees. The two referee system was investigated against the competing 'diagonal system', which was the system adopted in world football. The two-referee system was considered before the diagonal system was adopted in 1938, after the redrafting of the Laws of the Game by Sir Stanley Rous. ${ }^{57}$

Harper was chosen as linesman alongside E. Pinckston of Birmingham in the second of these trial matches following the perceived success of the initial trial. The first trial match took place on $5^{\text {th }}$ January 1935 and was an Amateur International Match officiated by Dr. A. W Barton and E. Wood. The general opinion of the first trial was 
favourable because, '... the experiment minimized the amount of work and enabled the officials to keep up with the play, ${ }^{58}$ The second match, involving Harper, was to be the 'second official trial of the much-discussed two-referee plan by the International Selection Committee' with the officials in question ' ... regarded as the foremost referees of the day, 59

Following his selection as linesman in the second two-referee trial match, a letter to Harper from the Football League Management Committee states that it was hoped that linesmen would not be required in the third trial match for the first half. The letter states that Harper would only be employed in the second half if it was decided that they were required at half time if ' $\ldots$ the experiment ... does not work satisfactorily. ${ }^{60}$ Following the trial match Harper wrote a report to Worcestershire FA concerning his views of the successfulness of the trial, also shedding light on whether the additional linesmen were required in the second half of the match. Harper reported that he felt the trial had been a success outlining that, 'the assistance of linesmen being dispensed with I found, under the circumstances, not only possible but satisfactory, in this match'. Harper continued to argue that he felt the second trial match had been more successful than the first trial match:

\footnotetext{
Mr Pinckston and myself, as is well known, acted as linesmen in the Inter-National trial game, England v The Rest, at West-Bromwich, when two referees were also engaged, but the result of the dual control was not, in my opinion, successful, or probably better may I suggest, not demonstrated to the public convincingly. The control of the game on May $8^{\text {th }}$, having been left entirely to the two officials, we found that we were able to dispense with linesmen, and on being request at halftime if we required the assistance of linesmen, we decided in the negative. ${ }^{61}$
}

Despite some perceived success of the trial, as well as the media coverage of the games and the trial more generally, newspaper reports specifically commenting on the 
two referee system believed that it was ' ... too easy' and that both referees ' ... didn't have enough to do'. ${ }^{62}$ Another newspaper report from 1935 explains both side of the argument by supporting and challenging the proposed two referee system. Positive comments such as 'two better than one' and '... the pace has become too fast for one referee' are tempered by more negative comments such as 'opinions are very divided on the two referees system' as well as '... referees generally dislike the scheme'. ${ }^{63}$

The trial matches did not extend to anything other than a trial. The two-referee system was never implemented, although the media interest and press coverage was evident from the newspaper cutting and letters preserved by Harper at that point in his career.

\section{Conclusion}

W.P. Harper believed that the media and press contributed to the increased pressure for referees, and also for inflating the issues within some of the matches that he officiated. In a newspaper column Harper wrote for Thomson's Weekly News he argued that these were, 'incidents' which are magnified out of their real proportions'. ${ }^{64}$ Whether the decisions that Harper gave were correct or incorrect and whether they affected the outcome of the matches that have been discussed here is not necessarily the issue. The fact that there was evidently a growing culture during the 1930s of the media, and in particular the written press, identifying the referee as an individual that could impact the game, began to set a precedent that continued to evolve as Association Football itself developed as a game.

Figure 9 near here.

There was inarguably a developing narrative, in its infancy during the 1930s, where the referee was becoming subject to increased scrutiny and part of the discussion of the game in the public domain. Pictures, stories and headlines attributed to the match 
official were becoming more prevalent and much of this was set against a backdrop of a lack of training, support and structure for referees, leaving them unequipped to deal with the scrutiny to which they were now afforded. ${ }^{65}$

This growing trend within the media, focusing on the central nature of referee decision making and the impact that these decisions might have on a game, was something that would continue as new forms of media such as the radio and, more importantly, television began to become more widespread in terms of their use and coverage of football matches. Perhaps referees, and those involved with refereeing, believed that this interest in the match official and their performance would dissipate over time, that this interest in the referee would dilute and that they would be permitted to return to a measure of anonymity and absence from match reports and press interest. This did not happen.

Referees became much more of a focus than had historically been the case. They became a part of the narrative and this became a growing concern for those involved with refereeing. We can return to the work of Stanley Cohen for a final thought on the changes that were becoming evident for referees in the 1930s. Cohen argues that, ' ... the media might leave behind a diffuse feeling of anxiety about the situation: 'something should be done about it', 'where will it end?' or 'this sort of thing can't go on for ever. ${ }^{66}$ For W.P. Harper and other referees during the 1930s however, they were experiencing the infancy of a growing interest in and appetite for Association Football alongside a sustained interest in the referee as an increasingly central figure in the evolving game. The media fascination with referees had begun.

\section{Notes on Contributor}

Tom Webb is a Senior Lecturer in Sports Management and Development at the University of Portsmouth. His current research considers elite refereeing in association 
football across European Leagues.

\section{Notes}

${ }^{1}$ The W. P. Harper collection (Harper's personal papers) resides at the Worcestershire Archive and Archaeology service, Worcester, (WAAS), 899.195, BA 1786.

${ }^{2}$ Sharon Colwell, "’Public Enemy No. 1!'e: Television, Commentators and Our Perception of Referees', in P.J. Murphy (ed.), Singer \& Friedlander Review 2000-2001 Season (London: Singer \& Friedlander Investment Funds, 2001a), $50-55$.

${ }^{3}$ T. Webb, and R. Thelwell, “"He's Taken a Dive”: Cultural Comparisons of Elite Referee Responses to Reduced Player Behaviour in Association Football', Sport, Business and Management: An International Journal 5, no. 3 (2015), 242-258.

${ }^{4}$ Tony Mason (ed.), Sport in Britain: A Social Issue (Cambridge: Cambridge University Press, 1989); Tony Mason, 'All the Winners and the Half Times... ', The Sports Historian 13, (1993), 3-13; Gary Whannel, Media Sport Stars: Masculinities and Moralities (London: Routledge, 2002).

${ }^{5}$ J. Horne, A. Tomlinson, and G. Whannel, Understanding Sport: An Introduction to the Sociological and Cultural Analysis of Sport (London: Spon, 1999).

${ }^{6}$ Mason, 'All the Winners', 7; Grant Jarvie, Sport, Culture and Society: An Introduction (London: Routledge, 2006), 136.

${ }^{7}$ Barry Smart, The Sport Star: Modern Sport and the Cultural Economy of Sporting Celebrity (London: Sage, 2005), 66.

${ }^{8}$ Matthew Taylor, The Association Game: A History of British Football (Harlow: Pearson, 2008), 145.

${ }^{9}$ Ibid. 145-146.

${ }^{10}$ Tom Webb, 'The Emergence of Training and Assessment for Referees in Association Football: Moving from the Side-Lines', The International Journal of the History of Sport 31, no. 9 (2014a), 1081-1097. 
${ }^{11}$ Matthew Nicholson, Sport and the Media: Managing the Nexus (Oxford: Elsevier, 2007), 21.

${ }^{12}$ Taylor, The Association Game, 148.

${ }^{13}$ Richard Haynes, 'A Pageant of Sound and Vision: Football's Relationship with Television, 1936-60', International Journal of the History of Sport 15, no. 1 (1998), 211-226.

${ }^{14}$ Stephen Wagg, The Football World: A Contemporary Social History, (Brighton: The Harvester Press, 1984), 41.

${ }^{15}$ Sharon Colwell, 'Elite Level Refereeing in Men's Football: A Developmental, Sociological Account', (PhD diss., Department of Sociology, University of Leicester, 2004), 295.

${ }^{16}$ Ellis Cashmore, Making Sense of Sports, (London: Routledge, 2000), 278-8.

${ }^{17}$ Jackson \& Toms, "The first modern ref," 118-124.

${ }^{18}$ Wall to Harper, July 26, 1927, (WAAS), 899.195, BA 1786.

${ }^{19}$ Athletic News, 27 December 1926.

${ }^{20}$ Mather to Wall, 4 February 1926, (WAAS), 899.195, BA 1786.

${ }^{21}$ Harper to Wall, 8 February 1926, (WAAS), 899.195, BA 1786.

${ }^{22}$ Ibid.

${ }^{23}$ Harper to Wall, 18 September 1928, (WAAS), 899.195, BA 1786.

${ }^{24}$ H. J. Weber, letter to the editor, Sporting Life, 15 January 1930.

${ }^{25}$ Ibid.

${ }^{26}$ Evening News, 15 January 151930

${ }^{27}$ Weber to Harper, 17 January 1930, (WAAS), 899.195, BA 1786.

${ }^{28}$ Evening News, 15 January 1930.

${ }^{29}$ Ibid.

${ }^{30}$ Sunday Pictorial, 31 December 1933.

${ }^{31}$ Topical Times, 21 July 1934

${ }^{32}$ Rose to Harper, 24 February 1931, (WAAS), 899.195, BA 1786.

${ }^{33}$ Oldham Evening Chronicle, 24 April 1933. 
34 “A Real Revival.” Burton Town FC Official Programme, Number 590, 12 January 1935.

${ }^{35}$ The County Express, 9 June 1936.

${ }^{36}$ Swindon Evening Advertiser, 19 September 1938.

${ }^{37}$ Irish Press, 8 February 1932.

${ }^{38}$ Irish Independent, 20 February 1932.

${ }^{39}$ Barrington to Harper, 22 February 1932, (WAAS), 899.195, BA 1786.

${ }^{40}$ E. Goode, and N. Ben-Yehuda, 'Moral Panics: Culture, Politics and Social Construction', Annual Review of Sociology 20, (1994), 149-171.

${ }^{41}$ Arnold Hunt, "'Moral Panic" and Moral Language in the Media', The British Journal of Sociology 48, no. 4 (1997), 629-648; A. McRobbie, and S. L. Thornton, 'Rethinking "Moral Panic” for Multi-Mediated Social Worlds', The British Journal of Sociology 46, no. 4 (1995), 559-574.

${ }^{42}$ Stanley Cohen, Folk devils and Moral Panics: The Creation of the Mods and Rockers, (London: MacGibbon and Kee, 1972), 29

${ }^{43}$ Ibid.

${ }^{44}$ Ibid. 29-30.

${ }^{45}$ Elizabeth Pike, 'The Active Ageing Agenda, Old Folk Devils and a New Moral Panic', Sociology of Sport Journal 28, no. 2 (2011), 209-225.

${ }^{46}$ Chas Critcher, Moral Panics and the Media, (Buckingham: Open University Press, 2003), 2.

${ }^{47}$ Allison Cavanagh, 'Taxonomies of Anxiety: Risk, Panics, Paedophilia and the Internet', Electronic Journal of Sociology: (2007), 1-16.

${ }^{48}$ Goode and Ben-Yehuda, 'Moral Panics', 156-159.

${ }^{49}$ Ibid. 161.

${ }^{50}$ Stanley Cohen, Folk Devils and Moral Panics, (London: Routledge, 2002) xi.

${ }^{51}$ McRobbie, and Thornton, 'Rethinking "'Moral Panic", 572.

${ }^{52}$ Wall to Harper, 11 April 1932, (WAAS), 899.195, BA 1786. 
${ }^{53}$ Spiers to Harper, 29 February 1932, (WAAS), 899.195, BA 1786.

${ }^{54}$ Bunnell to Harper, 1 March 1932, (WAAS), 899.195, BA 1786.

${ }^{55}$ Thomson's Weekly News, 30 July 1932.

${ }^{56}$ Wall to Harper, 11 April 1932, (WAAS), 899.195, BA 1786.

${ }^{57}$ David Goldblatt, The Ball is Round: A Global History of Soccer, (New York: Riverhead Books, 2006), 516-517; Stanley Rous, Football Worlds: A Lifetime in Sport, (Newton Abbot: Readers Union, 1978), 86-89.

${ }^{58}$ Topical Times, 16 February 1935.

${ }^{59}$ Topical Times, 16 February 1935.

${ }^{60}$ Rinder \& Bassett to Harper, 30 April 1935, (WAAS), 899.195, BA 1786.

${ }^{61}$ Harper to Rinder, Basset \& The Football League Management Committee, 8 May 1935, (WAAS), 899.195, BA 1786.

62 'Leaves from my notebook', Sheffield Telegraph and Star Sports Special, 30 March 1935.

63 'Leaves from my notebook', Sheffield Telegraph and Star Sports Special, 16 March 1935.

${ }^{64}$ Thomson's Weekly News, 9 July 1932.

${ }^{65}$ Webb, 'The Emergence of Training'; Webb, 'Elite Refereeing Structures'.

${ }^{66}$ Stanley Cohen, Folk Devils and Moral Panics: The Creation of the Mods and Rockers, (Oxon: Routledge, 2011), 55. 